\title{
PRACTICAL ACTIVITIES ALLOW STUDENTS WITH DISABILITIES TO DEVELOP AN UNDERSTANDING OF THEIR ENVIRONMENT AND THEMSELVES
}

\author{
Ilga Prudnikova \\ Rezekne Academy of Technologies, Latvia
}

\begin{abstract}
The research problem was to find answer to the question: how did the role of practical tasks and activities in the education of students with moderate/severe disabilities is an important one. A review of current and past theories of cognitive development focusing on the role of experiential learning because for today's students with disabilities there is a stronger emphasis on practical skills and motor skills development opportunities than on traditional learning approaches. Home Economics and Its Technologies is one of the subjects in today's curriculum where time is allocated to activity-based learning and experiences. Occupational therapy has a positive effect on the child's psyche, helps to manage and organise the child's impulses, renews and promotes appropriate work habits, helps organise his/her activities and reduces the child's focus on his/her own shortcomings or disabilities.
\end{abstract}

Keywords: students with disabilities, moderate/severe disabilities, special education, curriculum, Home Economics and Its Technologies, the educational process.

\section{Introduction}

The popularity of teaching everyday work skills in schools is longstanding as demonstrated by the fact that in Latvia's 1925 overall curriculum plans "almost one third of the mandatory lessons for students were dedicated to subjects who required activity-based learning by the students" (Antalogija, 1994, 14).

The pedagogue, Cirulis, a Latvian educator and expounder of "trade schools" and the most prodigious creator of systemic approaches for the use of activity-based learning in teaching of handicrafts in Latvia, stresses that the aim of teaching handicrafts is not to teach the student a trade but to aid the student's physical and emotional development. One subject in today's curriculum that includes activity-based learning through a range of topics or units, including the teaching of handicrafts, is Home Economics and Its Technologies (Цируль, 1890).

The subject of home economics has had many name and content changes over the years. If, originally, home science was viewed only as a practical subject with limited possibilities, then today it has become a man-faceted way of helping in the overall personal development of the student. This movement has 
been influenced by social and economic changes as well as the community's changed expectations of formal education. Home Economics and Its Technologies was associated with the preparation of the student for work, as well as teaching specific practical skills, neglecting the opportunity to use this subject to aid the overall development of the student. Today it is a complex subject with multiple directions, technologies and skills which also uses and tests the student's ability to generalise knowledge gained in other subjects. It is one of the subjects in today's curriculum where time is allocated to activitybased learning and experiences. By completing set activities the student becomes familiar with the major steps of the task, as well as becoming familiar with the tools or instruments that will allow him/her to complete the task effectively. It has moved from teaching and learning of practical tasks to promoting the overall personal development of the student.

Vygotsky stressed that special education must be linked to regular education in that it should follow the same principals as general education, that is that education must lead development (Vygotsky, 1983, 50-60). He discusses students with disabilities in terms of their "primary" and "secondary" disabilities and their interactions. The primary disability is the impairment due to biological factors but this is compounded by distortions to higher psychological functions due to social factors. Vygotsky sought to define a student with disabilities from a point of strength calling this "positive differentiation". He also argued that scaffolding of learning through the assistance of an adult supports the development of emerging abilities revealing the potential of the student. This process, the Zone of Proximal Development, utilises appropriate assistance from an adult or more advanced peer to assist with learning as Vygotsky's theories place a strong emphasis on culture affecting cognitive development.

For today's students with disabilities there is a stronger emphasis on practical skills and motor skills development opportunities than on traditional learning approaches (Florian, 2007). Freimanis reinforces this when he states that lessons need to focus on well-defined activity-based learning (Freimanis, 2007). Subject - specific teaching and learning programs should focus on activity-based experiences across a range of situations because "sensory experiences and words are the key to the formation of concepts, but words removed from sensory experiences transfer the process to a verbal sphere which is not characteristic for children" (Vygotsky, 2002, 120). For this reason one of the biggest challenges facing remedial education today is the preparation of students for the workforce (Liepina, 2008). Similarly Freimanis states that "occupational therapy has a positive effect on the child's psyche, helps to manage and organise the child's impulses, renews and promotes appropriate work habits, helps organise his/her activities and reduces the child's focus on his/her own shortcomings or disabilities" (Freimanis, 2007, 180) 
Students with moderate/severe disabilities need to participate in real but guided experiences. They need the opportunity to experience multiple activities and their consequences. They need to be able to share their experiences in order to enrich their lives.

The aim of this paper is to analyse the literature, Latvian policies and national directions and evaluate personal experience in order to identify the role of practical tasks and activities in the education of students with moderate/severe disabilities is an important one.

\section{Theoretical guidelines}

Dewey (1974) believed that experience was the basis of all learning. However the experience itself is not sufficient for learning to occur. Bacon (1989) asserted that knowledge comes primarily from sensory experience but this needs to be processed, to be made sense of, in order to generalise the knowledge to other situations. Locke (1977) also stressed that the experience itself was not knowledge but that knowledge grew from it.

Bruner (1996) believed that cognition developed through interaction with the environment and that it developed in the move from the concrete to the abstract. Rogers (1994) also favoured experiential learning but for the best outcomes teachers need to provide a positive climate, clarify the purpose, organise the resources, balance intellectual and emotional components and share feelings, all without dominating.

Vedins (2008) states that all students can learn as all people are born with the ability to explore their environment through their senses. Positive, practical activities allow students to develop an understanding of their environment and themselves.

However more than "direct" experience is needed, the experience also needs to be corrected to become a "true" experience. It is through the identification of discrepancies and making sense of them that students can return to a sense of equilibrium which Piaget (2002) sees as crucial for the learning process. One way of making sense of an experience is through socio/cultural interaction according to Vygotsky (2002). Teachers need to create an environment which will encourage participation and Vygotsky identifies the use of the Zone of Proximal Development as a way for the adult to promote student learning.

As students with disabilities come from a range of environments with a range of experiences, mediation of experiences is important. This mediation can take various forms such as deliberate practice (Vedins, 2008), the use of language (Vygotsky, 2002; \& Piaget, 2002), changing attitudes (Spona, 2001), reflection (Broks, 2007; Boud et al., 1985) and feedback (Race, 2010). 
Kolb (1984) identified a cycle of experiential learning which involves a concrete experience, reflective observation, abstract conceptualisation, active experimentation. Honey and Mumford (1992) preferred to identify the process as a spiral as the process involves constant development and Race (2010) as a series of ripples which impact on one another and which are driven by the student's wants or needs and impacted upon by feedback.

Liepina (2008) notes that students with disabilities need instruction, practical demonstration and the use of appropriate language i.e. precise and concise. Knowledge of fundamental concepts (e.g. size, shape, number) is a prerequisite for students being able to use experiences, to identify similarities or differences and to move to further learning.

\section{Organisation of the educational process for students with moderate/severe disabilities}

In Latvia, the National Primary Education Standard sets the overall goals and requirements of education, but the Special Education Curriculum seeks to implement these through the development of Individual Educational Programs (IEPs) for students with disabilities. For students with moderate/severe disabilities these IEPs are developed jointly by the student's parents and teacher. The process focuses on the student's needs and abilities, taking into account the student's experiences, skills, cognitive development as well the National Primary Education Standard and the goals and objectives of each subject. This type of plan is viewed as a "remedial education program whose methodology and structure is appropriate for people of a mandatory schooling age who require additional support with their primary education" (General Education Law, 1999, 1.p.).

Home Economics and Its Technologies, together with subjects such as Latvian and World History, Social Science, Sport, Ethics and Religious (Christian) Education fall within the overall area of Citizenship and Society the major objectives of which are to:

- develop and understanding of emotional and physical development and the obligations of citizenship;

- develop an understanding of lifelong learning;

- develop expertise in understanding and expressing the student's own point of view about past and present events;

- develop communication and interaction skills;

- promote a proactive approach to life in the community and develop the citizenship skills for participation in a democratic society;

- develop independent learning skills (MK Regulations, No. 468, 2014). 
The Special Education Curriculum Model for students with disabilities or multiple disabilities defines:

- the education program's goals and objectives;

- the content;

- the implementation plan;

- requirements relating to prior learning;

- the necessary human, financial and material resources for the implementation of the educational program based on the health and development needs of the student.

This model aims to secure the implementation of IEPs to facilitate "practical skills development" for students with disabilities. In instances where the motor and cognitive skills development is extremely impeded, the school can develop a remedial program that is not tied to specific timetabled subjects (Sample special primary education program for students with moderate/severe disabilities and severe developmental disorders, 2009).

The Special Education Curriculum has, from the beginning of schooling, a greater emphasis on activity-based, practical subjects than the regular education curriculum because activity-based learning:

- encourages intellectual activity;

- promotes attending behaviours;

- $\quad$ is instrumental in strengthening the student's will;

- develops work skills and ethics (Liepina, 2008, 310).

Organisation of the educational process for students with moderate/severe disabilities is as follows:

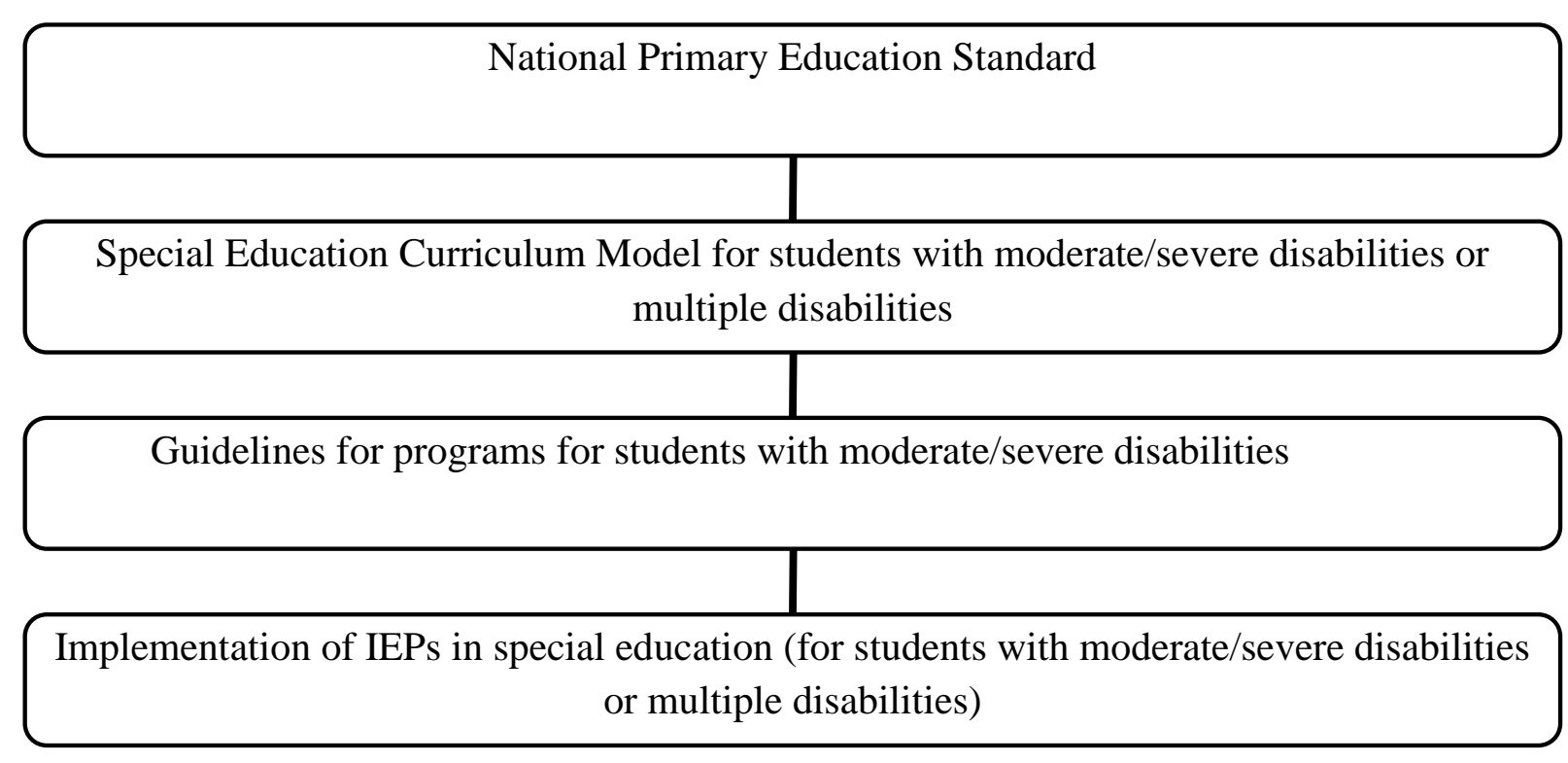

Figure 1 Organisation of the educational process 
An individual approach is developed in conjunction with the specific student taking into account "the psychological, physical, intellectual, social and behavioural characteristics" and it places the student in the centre of the process, taking into account his/her needs and interests in order to foster development of an understanding of home economics and the social interaction process (Freimanis, 2007, 73). Special schools (institutions) need to implement special education programs appropriate for the special needs of the students which comply with the demands of the educational institution (Liepina, 2008; Freimanis, 2007), taking into account the following operating principles:

- educational content which is practically orientated;

- a comprehensive review of the student and his/her needs;

- interaction between the teacher, year advisor and parents in developing the IEP so that the student can live as independently as possible;

- accessing opportunities for work and contributing to life in the community;

- development of work-related skills so the student is able to find employment post-school;

- creation of a data base which details the student's development and his/her learning and health needs;

- preparation of all those involved in supporting the integration of the student into the life of the school (parents, teachers, health workers, other students);

- appropriate adaptations to enable students with severe physical disabilities to participate;

- co-operation with special education development centres.

All special education settings in Latvia work towards expanding the functions of the setting as is reflected by the enrolment numbers of students with moderate/severe disabilities (Level C) in special schools. "...As students with disabilities find it more difficult to develop work skills and competencies than their normal peers" (Liepina, 2008, 311) it is necessary to provide more opportunities for practice, more repetition. This is compounded language learning difficulties which impact on understanding oral instructions but even more so on the comprehension of written or diagrammatical instructions. Problems also arise when generalising skills to other situations (Liepina, 2008; Friend, 2005). Rubinstein emphasised that "for the development of all mental processes, help from the teacher is crucial" (Рубинштейн, 1986). For this reason in $\mathrm{C}$ Level classes there is both a teacher and an assistant teacher (not a teacher's aide). 
The first $\mathrm{C}$ Level classes were opened in Riga's $5^{\text {th }}$ Primary Boarding School, and in Liepaja's and Daugavpils' special schools. They were the first step in integrating students with moderate/severe disabilities (C Level) into special schools. In the 1990/91 school year, there were 15 students with moderate/severe disabilities in $\mathrm{C}$ Level classes in 2 special schools. In the 1996/97 school year this had grown to $62 \mathrm{C}$ Level classes in 27 special schools which provided education for 366 students. In 2001 this had risen to 703 students, in 2005 to 1125 students and in 2015 to 1557 students (IZM Statistics and Data Analysis Division).

The data shows that most special schools continue implementing IEPs for students with moderate/severe disabilities for another three years after they finish their primary education, which finishes in Year 9 in Latvia. Based on the student's needs, his/her health and the opportunities provided by each setting, the students are prepared for life and work in the community. The subject Home Economics and Its Technologies combines learning at school with the students' everyday experiences and the skills required for life in the community. Information which has been learned by the students through experience and everyday interaction with their families is extended. This is an important period in the life of students with moderate/severe disabilities, as the opportunities provided by the school to develop skills, attitudes and knowledge cannot be replicated just through family interactions.

As can be seen from the Figure below, Home Economics and Its Technologies requires the systematic teaching of specific skills.

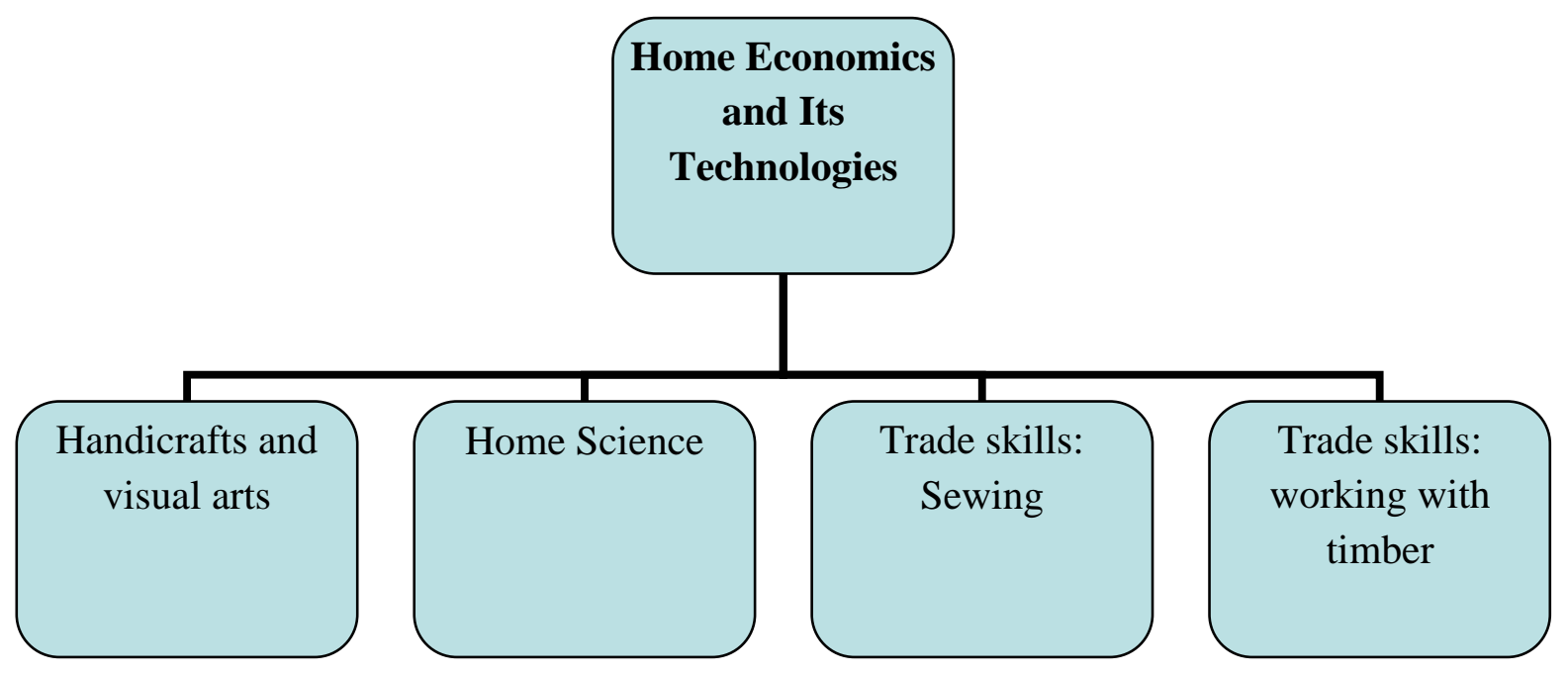

Figure 2 The content of Home Economics and its Technologies 
Within the abovementioned units the focus is on helping students to gain insights about the man-made environment, to develop work skills specific to each unit as well as skills related to maintaining and using leisure environments.

They acquire the skills to model and shape materials such as paper, natural materials, textiles, wire, and plasticine and other materials. They learn to be responsible for their work, to work individually or in a group, skills for working with pencils, rulers, scissors, needles, to observe rules for occupational safety, to master the technologies used in production (e.g. timber) as well as the basics of design, to use the tasks for self-expression, to assess their work and that of their peers and others, prepare for life and work in the community.

Each student, according to his/her state of health, abilities and level of development is ensured opportunities, to learn to live in a rapidly changing society while at the same time the student is provided with the pedagogical, psychological and medical support required. Students come to understand how they can achieve their full potential, which will ensure both their and society's welfare in the future.

The focus is on motor development, beginning with hand and finger exercises and then whole-body movement coordination as, even though these activities, through the mastery of elementary skills, it is possible to support the development of speech, the ability to think, to make purposeful movements, to develop emotions and willpower. The main aim of these activities is "for the child to comprehend the activity, no matter how basic or primitive" (Liepina, 2008; 134).

The aims for Home Economics and Its Technologies are as follows:

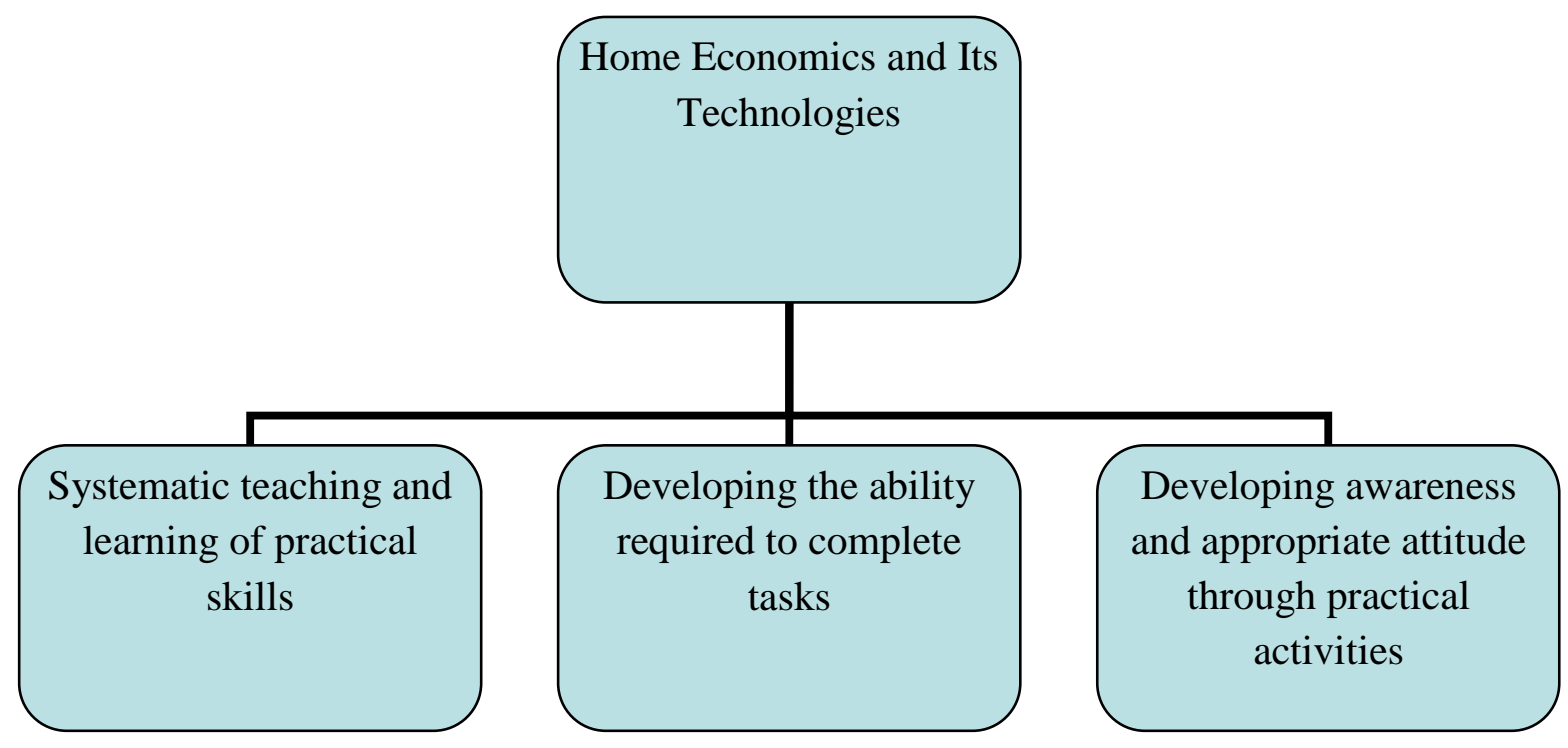

Figure 3 The goals of Home Economics and its Technologies 
The needs of the student are paramount for the development of an IEP which addresses all subject areas including Home Economics and Its Technologies. This plan, based on the skills and abilities of the student, includes:

- developing an understanding of equipment, food, cleaning, cooking, and knowledge of the personal significance of these activities as well as the motivation to complete these practical activities (Home Science);

- developing an understanding of materials, tools, equipment, the use of equipment (technologies used) and materials, and knowledge of the personal significance of these activities as well as the motivation to complete these practical activities (handicrafts and visual arts);

- developing an understanding of working with textiles and the associated technology, the skills to use this technology, and knowledge of the personal significance of these activities as well as the motivation to complete these practical activities (Trade skills, Sewing);

- developing an understanding of wood working and the relevant tools, skills in using appropriate technology, and knowledge of the personal significance of these activities as well as the motivation to complete these practical activities (Trade skills, Woodwork).

It is important for students with moderate/severe disabilities, for the teaching Home Economics and Its Technologies to commence in the primary school building on prior learning and knowledge. Then, through the use of systematic and sequential teaching, to expand the student's interests and knowledge, so that the student is aware of his/her needs, goals and interests and can work towards achieving these in the future.

\section{Conclusions}

Students with moderate/severe disabilities need to participate in real but guided experiences. They need the opportunity to experience multiple activities and their consequences. They need to be able to share their experiences in order to enrich their lives.

The role of practical tasks and activities in the education of these students is an important one. Cognitive, humanistic, social and constructivist learning theories stress the importance of making sense or meaning from experiences.

A review of current and past theories of cognitive development focusing on the role of experiential learning is linked to implications for practice as well as to current Latvian policies and national directions. As well the subject, Home 
Economics and its Technologies is used as an example of an experiential learning structure which utilises previous experiences to enhance current and future learning.

The investigation of research literature on disabilities and the impact on the cognitive development of students with moderate/severe disabilities, leads to the conclusion that such students have a right to have their own learning systems, where the school's environment supports the students with disabilities to undertake purposeful learning tasks, ensuring that these are appropriate to their needs and which utilise sequential and multi-level activities and provide opportunities for learning through practice.

The subject Home Economics and its Technologies is, by its very nature, a practical subject. It fits within the overall education area of Citizenship and Society and it aims to develop students into life-long and independent learners, with an understanding of the rights and obligations of citizenship in a democratic society, as well as developing skills in communication, interaction and community participation. It is divided into four units and each unit is designed to develop the students' knowledge, skills and attitudes through the completion of practical activities.

As can be seen, learning through practice is made up of several phases of experiences which impact on the student's motivation, skills and attitudes which lead to new learning. This process can be supported through the use of Individual Educational Plans (IEPs) where teachers and parents can assess student needs, set goals, use specific prior experiences to promote new learning, use appropriate feedback to support the student's scaffolding of his/her learning in order to encourage active participation and further learning. This can be done in a regular setting, but specialist classes (C Level) are growing in popularity in Latvia.

\section{References}

Antologiija, (1994). Pedagogiskā doma Latvijā no 1890. g. lìdz 1940. g. Rīga: Zvaigzne. Bēkons, F. (1989). Jaunais organons. Rīga: Zvaigzne.

Boud, D. et al., (1985). Reflection. Turning Experience into Learning. London: Kogan.

Broks, A. (2007). Science education as life experience for life. Proceedings of 6th IOSTE Symposium for Central and Eastern Europe „Science and Technology Education in Central and Eastern Europe: Past, Present and Future", Siauliai University Publishing House, p. 26-30.

Bruner, J. (1996). The Culture of Education. Cambridge, Masschusetts, London, England: Harvard University Press, ix.

Dewey, J. (1974). Experience and Education. New York: Collier Books.

Ericson, E. H. (1993). Childhood and Society, W. W. Norton \& Company, publiced 1964.

Florian, L. (2007). The SAGE Handbook of Special Education. British Library, Cataloguing in Publication data. 
Freimanis, I. (2007). Ieskats speciālās skolas darbā. Rīga: RaKa.

Friend, M. P. (2005). Special Education: Contemporary Perspectives for School Professionals. Pearson Education. Inc.

General Education Law (1999). Downloaded from www.ndg.lv/latvian/.../Visparejas\% 20izglitibas\%20likums.doc Hattie and Timperley, 2007

Honey, P., \& Mumford, A. (1992). The Manual of Learning Styles. Peter Honey Publications, 3 Rev Ed edition.

IZM Statistics and Data Analysis Division. Downloaded from http://www.izm.gov.lv/lv/ publikacijas-un-statistika/statistika-par-izglitibu/statistika-par-visparejo-izglitibu/20142015-m-g

Kolb, D. (1984). Experiential learning: experience as the source of learning and development. Englewood Cliffs, N. J.: Prentice Hall. xiii

Liepiña, S. (2008). Speciālā psihologija. Rīga: RaKa.

Loks, Dž. (1977). Eseja par cilvēka sapratni. Rīga: Zvaigzne.

MK Regulations, No. 468 "Noteikumi par valsts pamatizglìtības standartu, pamatizglìtības mācību priekšmetu standartiem un pamatizglītības programmu paraugiem”, (2014). Downloaded from likumi.lv/doc.php?id=268342

Piažē, Ž. (2002). Bērna intelektuālā attīstība. Rīga: Pētergailis.

Race, P. (2010). Making Learning Happen. 2nd Edition, London: Sage Publications.

Rogers, C. R. (1994). Freedom to Learn: A View of What Education Might Become. Columbus: CE. Merrill Publishing, publiced 1969, x.

Sample special primary education program for students with moderate/severe disabilities and severe developmental disorders, (2009). Downloaded from http://visc.gov.lv/ specizglitiba/dokumenti/programmas/smag/majturiba1-9_spec_smag.pdf

Špona, A. (2001). Audzināšanas teorija un prakse. Rīga: RaKa.

Vedins, I. (2008). Zinātne un patiesība. Rīga: Avots.

Vigotskis, L.. (2002). Domāšana un runa. R.: EVE.

Выготский, Л. С. (1983). Собрание сочинений в 6 томах. Т. 5: Основы дефектологии. Москва: Педагогика.

Выготский, Л. С. (2005). Психология развития человека. Москва: Изд-во Смысл; Изд-во Эксмо.

Рубинштейн, С. Я. (1986). Психология умственно отсталого школьника. 3 - е изд., перераб. и доп. Москва: Просвещение.

Цируль, К. (1890). Ручной труд в народной школе. Москва, 31 с. 